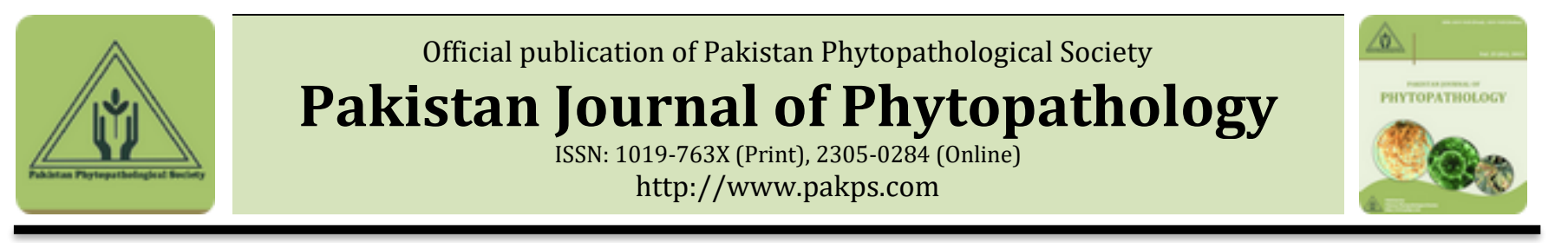

\title{
EVALUATION OF SESAME CULTIVARS AND FUNGICIDE SEED TREATMENT AGAINST FUSARIUM WILT DISEASE (FUSARIUM OXYSPORUM F. SP. SESAMI) IN WESTERN TIGRAY, NORTHERN ETHIOPIA
}

\author{
assefa A. Kebede*, bHadush Tsehaye \\ a Tigray Agricultural Research Institute, Humera Agricultural Research Center, P. O. Box 62, Humera, Tigray, Ethiopia. \\ b Dryland Crop and Horticultural Sciences, Mekelle University, P. O. Box: 231.
}

\section{A B S T R A C T}

Sesame is an important oil crop in Ethiopia produced mainly for international market, but its production is challenged by several abiotic and biotic factors. Among the biotic factors sesame Fusarium wilt disease caused by Fusarium oxysporum f. sp. sesami is the major threat for sesame production and inflicts great yield losses. The objective of the present study was to evaluate the effect of fungicide seed treatment and to assess differences in the Ethiopian sesame cultivars for resistance to Fusarium wilt disease. Field experiment was conducted at May-kadra and Dansha locations during the 2018 cropping season using eight cultivars and two fungicides as seed treatment. Besides, untreated seeds were left as control. Treatments were evaluated with split plot design arrangement with three replications. Fungicide seed treatment was used as main plot and sesame cultivars as sub-plot treatments. Fungicides seed treatment was significant effect at initial date of assessment or in the early crop growth stage. However, in the rest of assessment dates there were no significant effect of fungicide seed treatments in reducing Fusarium wilt disease incidence in both locations. Carbendazim 50\% EC was the most effective fungicide in controlling Fusarium wilt disease compared to the other fungicide tested (Thiram 75\% WP). There was significant $(\mathrm{p}<0.001)$ variation among the tested sesame cultivars with regard to disease incidence, AUDPC, stand count at maturity and seed yield in both locations. Cultivars Gojam-azene and Hirhir had the lowest disease incidence and AUDPC in both locations. The highest Fusarium wilt disease incidence was recorded from sesame cultivars Setit-3 and Achawuchey. The highest yield was recorded from Hirhir cultivar in both locations. Cultivars with low disease incidence could be useful in breeding programs aimed at developing varieties with higher resistance to Fusarium wilt disease.

Keywords: Fusarium wilt disease, incidence, Fusarium oxysporum f.sp. sesami, Resistance, Sesame cultivars.

\section{INTRODUCTION}

Sesame (Sesamum indicum L.) is one of the most important and oldest crops domesticated by man and cultivated throughout the world. The crop belongs to the family Pedaliaceae and is well known for its high quality seed (Ashri, 1998). Sesame is an important source of food worldwide and nutritionally serves as important sources of protein, fat, minerals and vitamins in the diets of rural populations,

Submitted: November 04, 2019

Revised: December 26, 2019

Accepted for Publication: May 19, 2020

* Corresponding Author:

Email: asse2008ec@gmail.com

(C) 2017 Pak. J. Phytopathol. All rights reserved. especially children. The crop is grown almost entirely in tropical and sub-tropical areas (Ashri, 1998). China and India are the highest sesame seed producers in the world, followed by Myanmar, Sudan, Uganda, Ethiopia, Nigeria, Tanzania, Pakistan and Paraguay (FAO, 2011). In Ethiopia, the dominant sesame producing regions are Tigray (33.05\%), Amhara (46.4\%), Oromia (12.75\%) and Benishangul Gumuz (7.8\%) (Central Statistical Agency (CSA, 2017-18). Western and southwestern zones of Tigray, Metema area in Amhara, east Welega in Oromia and Belles valley in Benishangul Gumuz are the major sesame growing areas in Ethiopia. In 2017-18, the total sesame production in the country was 2.56 million tons harvested from about 0.37 million hectares (ha) of land (CSA, 2017-18). Sesame is the second largest export 
commodity among the agricultural products of Ethiopia, generating a substantial amount of foreign currency and creating rural jobs (Sesame business network (SBN, 2013). However, the sesame yield per unit area is yet at very low, which is 6.91 quintals (qt)/ha (CSA, 2017-18). In addition to its inherent low genetic yield potential, a number of biotic and abiotic factors are responsible for the low productivity of sesame. Among the biotic factors, plant diseases are the major threat for sesame production in Ethiopia. The most wide spread diseases includes Fusarium wilt (Fusarium oxysporum f. sp. sesami), bacterial blight (Xanthomonase sesami), phyllody (Phytoplasma/Mycoplasma), powdery mildew (Oidium erysiphoides), Alternaria leaf spot (Alternaria sesame) and Cercospora leaf spot (Cercospora sesame) (Alemaw et al., 1997; Gupta et al., 2018; Terefe and Tulu, 1992). Among these diseases, Fusarium wilt caused by Fusarium oxysporum f. sp. sesami is one of the most important that infects sesame at all growth stages starting from seedling to maturity, causes sudden death of plants and causing heavy economic losses depending on the severity of infection (Alemaw et al., 1997; Gupta et al., 2018). The pathogen occurs throughout most sesame-growing areas worldwide causing vascular wilt and sesame fields infected with Fusarium wilt disease exhibits conspicuous patches of dead plants (Joshi et al., 2012; Kavak and Boydak, 2006). The fungus produces resting spores (Chlamydospores) that are resistant to unfavorable environmental conditions and it can survive on infected crop debris in the soil for about three to six years, with infection reoccurring from seeds or soil (Daita et al., 2018; Leslie and Summerell, 2006; Stover, 1962).

The use of disease free planting material (seeds) and breeding host plant resistance are the most effective and environmental friendly method of controlling Fusarium wilt disease. There is great variability in sesame germplasms in their resistance level against Fusarium wilt disease (El-Bramawy et al., 2001; Joshi et al., 2012; Kavak and Boydak, 2006). The available germplasm should be continuously evaluated to identify genotypes with resistance, which can be used directly for largescale cultivation in areas with high prevalence of the disease and to incorporate resistance to agronomical elite varieties. Hence, the present study was conducted to identify source of resistance among the Ethiopian sesame cultivars commonly grown in Tigray, northern Ethiopia. However, there are no sesame germplasms with complete (immune) or with adequate level of resistance to the pathogen (El-Bramawy et al., 2001; Joshi et al., 2012). Thus, integrating available resistance/tolerance varieties with other disease management measures such as fungicide seed treatment is crucial. Selective fungicides are commonly used as seed treatments to protect crops against seed and soilborne pathogens. Especially, applications of reduced dose of seed dressing fungicides and systemic resistance inducing chemicals were found to be effective in suppressing Fusarium wilt disease. Since chemicals in seed treatment are applied directly to seeds, they are not subject to spray drift and little is wasted on non-target sites such as bare soil. In addition, relatively small amounts of fungicides are used in seed treatments compared to spray treatments, which ultimately reduces the cost, the potential impact to the environment and the probability of chemical residues in harvested seed (Singh et al., 2016). Overall, application of single control measure against sesame Fusarium wilt disease is not effective. Thus, an integrated approach such as seed dressing using fungicides and deploying host resistant could be effective in managing sesame Fusarium wilt disease. Therefore, the present study was undertaken to evaluate the effectiveness of fungicide seed treatment in controlling Fusarium wilt disease as well as to assess differences in the Ethiopian sesame cultivars for resistance to Fusarium wilt disease and to selected resistance sesame cultivar(s) under field conditions.

\section{MATERIALS AND METHODS}

Description of study area: The field experiment was conducted during 2018 in main crop growing season at two locations: Kafta-Humera district at a specific locality known as May-Kadra and Tsegedie district at Dansha. The experimental sites are characterized by hot to warm temperature and high evaporation condition (hot to warm semiarid lowland agroecology). They differ mainly in their altitude, temperature and amount of annual rainfall. May-kadra site is located at $14^{\circ} 00^{\prime} 85^{\prime \prime}$ North latitude and $36^{\circ} 34^{\prime} 52^{\prime \prime}$ East longitude. The elevation of this station is about 646 meters above sea level (m.a.s.l). The mean annual temperature of the area is $29{ }^{\circ} \mathrm{C}$ and the rainy months extend from late June to the middle of September. The remaining 8-9 months are dry and hot. The dominant soil type is chromic black vertisol, deep clay with low organic matter content. While the Dansha site is situated at geographical coordinates of $13^{\circ} 38^{\prime}$ $421^{\prime \prime}$ North latitude and $36^{\circ} 32^{\prime} 9^{\prime \prime}$ East longitudes. The 
altitude of this experimental site is 624 m.a.s.l. The mean annual temperature of the Dansha area is $28.7{ }^{\circ} \mathrm{c}$. The area receives average annual rainfall of about $768.3 \mathrm{~mm}$ and the rainy months extend from June to September (Terefe et al., 2012).

Experimental materials and treatments: A total of 24 treatment combinations were used in the present experiment. Fungicide seed treatments were used as main plots and sub-plot treatments were consisted of different sesame cultivars. Fungicide untreated plots were left as control to allow maximum development of Fusarium wilt disease on each sesame varieties. Seeds of sesame cultivars were obtained from Humera Agricultural Research Center, which were maintained from crop grown in the immediate previous year. A total of eight cultivars currently commonly grown in the area were used as experimental material. The cultivars were four released varieties (Setit-1, Setit-2, Setit-3, and Humera-1), one local cultivar (Hirhir) and three other landraces (Gojam-azene, Keffif and Achawuchey). The fungicides used for seed treatment were Carbendazim $50 \%$ EC (systemic fungicide) and Thiram-75\% WP (contact fungicide). The rate or dose used for seed treatment for the test fungicides, Carbendazim 50\% EC and Thiram $75 \% \mathrm{WP}$, were $2 \mathrm{~mL}$ and $2.5 \mathrm{~g}$ per $\mathrm{kg}$ of sesame seed, respectively. The experiment was conducted under natural infected soil in Fusarium wilt disease prone (hot spot) areas.

Experimental design and management: The experiment was laid out in split plot design with three replications. Seed treatment using fungicides were

$$
\text { Disease incidence }(\%)=\left(\frac{\text { number of wilt infected plants }}{\text { total number of plants assessed }}\right) * 100
$$

Disease incidence was recorded by counting the infected plant compared to initial stand count and the reaction of sesame cultivars against Fusarium wilt disease were categorized according to the criteria provided by Dinakaran and Mohammed (2001) Table (1).

Table 1. Disease incidence scales used for evaluating varieties and varietal reaction categories

\begin{tabular}{cc}
\hline $\begin{array}{c}\text { Disease } \\
\text { incidence }(\%)\end{array}$ & Varietal reaction categories \\
\hline $1-10$ & Resistant (R) \\
$11-20$ & Moderately resistant (MR) \\
$21-30$ & Moderately susceptible (MS) \\
$31-50$ & Susceptible (S) \\
$>50$ & Highly susceptible (HS) \\
\hline
\end{tabular}

Area under disease progress curve (AUDPC) and disease progress rate: The area under the disease assigned to the main plots and the sesame cultivars to the subplots. Each treatment were randomly assigned into a plot area of $14.4 \mathrm{~m}^{2}$ (3 m row length and $4.8 \mathrm{~m}$ width), which consisted of 12 rows of sesame. The spacing between blocks, main plots and subplots were 2 $\mathrm{m}, 2 \mathrm{~m}$ and $1 \mathrm{~m}$, respectively. The spacing between plants and rows were $10 \mathrm{~cm}$ and $40 \mathrm{~cm}$, respectively. Seeds were sown on June 30 at Dansha and July 4, 2018 at May-kadra on three time's ploughed plots of land. Each experimental plot were received the same rate of NPS (100 kg/ha) and Urea (50 kg/ha) fertilizers. All NPS and half of the Urea $(\mathrm{N})$ fertilizer was applied during planting and the rest split of Urea was applied 45 days after planting (DAP). Recommended agricultural practices were applied at the proper time as per the local practice of sesame growing.

\section{Disease assessment}

Disease incidence: Fusarium wilt disease incidence was assessed starting from the time of disease appearance (25 DAP) until the crop attains its physiological maturity. Disease incidence was assessed five times from the middle rows of each plot at fourteen days interval based on specific disease symptoms. Plants affected by Fusarium wilt disease were characterized by yellowing, stunted growth, brown and black sign on the stem (vascular discoloration), appearance of plants wilted, died and fall down on the ground (Smith et al., 1988; Agrios, 2005; Leslie and Summerell, 2006). The percent of disease incidence was calculated using the following formula:

progress curve (AUDPC) was calculated from the disease incidence values using the formula proposed by Madden et al. (2007):

$$
A U D P C=\sum_{i=1}^{n-1} 0.5\left(\mathrm{X}_{\mathrm{i}}+1+X_{i}\right)\left(\mathrm{t}_{\mathrm{i}}+1-\mathrm{t}_{\mathrm{i}}\right)
$$

Where

$>\mathrm{X}_{\mathrm{i}}$ - Is the incidence percentage of the disease at $i^{\text {th }}$ assessment,

$>t_{i}$ - Is the time of the $i^{\text {th }}$ assessment in days from the first assessment date and

$>\mathrm{n}$ - Is the total number of disease assessments Agronomic parameters: Agronomic parameters such as initial stand count was recorded at $15 \mathrm{DAE}$ and final stand count per plot was recorded at crop maturity (81 DAE). The crop was harvested manually and the 
harvested plants were kept up-right in bencher locally known as hilla. The hillas were allowed to dry under the sun for two weeks and seeds were collected or threshed by shaking the dried bunch of plants upside down on plastic sheets. Then, finally grain yield per plot was determined.

Data analysis: Analysis of variance (ANOVA) was performed for disease parameters (incidence and area under disease progress curve), stand count at maturity and seed yield using Genstat version 18 software. The area under disease progress curve (AUDPC) was calculated from mean disease incidence values using the trapezoidal integration method and it is expressed in \%-days. Least Significant Difference (LSD) values were used to separate differences among treatment means at 5\% probability level. Linear correlation analysis was performed to determine the relationship between disease incidences, stand count and grain yield.

\section{RESULTS}

Effect of sesame cultivars and fungicide seed treatment on Fusarium wilt disease incidence: Fungicide seed treatments showed significantly $(\mathrm{p}<0.05)$ different effect on Fusarium wilt disease incidence compared to the untreated control on assessment dates made 25 DAE, 39 DAE and 53 DAE on both Dansha and May-kadra. However, there was no statistically significant variation in disease incidence among seed treatments on the other assessment dates. At $25 \mathrm{DAE}$, seed treatment using Carbendazim 50\% EC showed the lowest Fusarium wilt disease incidence $(0.95 \%)$ in Maykadra and $(1.83 \%)$ in Dansha compared to Thiram 75\% WP (1.39\%) in May-kadra and (1.84\%) in Dansha (Table $2)$. The highest disease incidence in both locations were recorded from untreated control plots (Table 2). In both locations the highest disease incidence was recorded at the last assessment date (81 DAE), 28.25\% in May-kadra and $37.39 \%$ in Dansha in the untreated control plots.

Table 2. Effect of fungicide seed treatment on sesame Fusarium wilt disease incidence in May-kadra and Dansha during 2018 cropping season

\begin{tabular}{lcccccccccc}
\hline Treatments & \multicolumn{1}{c}{ May-kadra } & \multicolumn{1}{c}{ Disease incidence (\%) } \\
\cline { 2 - 11 } & 25 DAE & 39 DAE & 53 DAE & 67 DAE & 81 DAE & $\begin{array}{c}25 \\
\text { DAE }\end{array}$ & 39 DAE & 53 DAE & 67 DAE & 81 DAE \\
\hline Carbendazim 50\% EC & $0.95^{\mathrm{c}}$ & $4.15^{\mathrm{b}}$ & $12.76^{\mathrm{b}}$ & 23.19 & 27.92 & $1.83^{\mathrm{c}}$ & $10.69^{\mathrm{b}}$ & $23.65^{\mathrm{b}}$ & 33.52 & 36.46 \\
\hline Thiram 75\% WP & $1.39^{\mathrm{b}}$ & $4.66^{\mathrm{a}}$ & $13.61^{\mathrm{ab}}$ & 23.74 & 28.04 & $1.84^{\mathrm{c}}$ & $11.24^{\mathrm{b}}$ & $25.13^{\mathrm{ab}}$ & 34.57 & 37.29 \\
\hline Untreated control & $1.83^{\mathrm{a}}$ & $5.02^{\mathrm{a}}$ & $14.02^{\mathrm{a}}$ & 24.04 & 28.78 & $3.32^{\mathrm{a}}$ & $12.25^{\mathrm{a}}$ & $25.89^{\mathrm{a}}$ & 35.48 & 38.41 \\
\hline LSD (5\%) & 0.29 & 0.36 & 1 & $\mathrm{~ns}$ & $\mathrm{~ns}$ & 0.49 & 0.89 & 1.97 & $\mathrm{~ns}$ & $\mathrm{~ns}$ \\
\hline Grand mean & 1.39 & 4.61 & 13.46 & 23.66 & 28.25 & 2.53 & 11.39 & 24.89 & 34.52 & 37.39 \\
\hline
\end{tabular}

DAE: Days after emergence, ns: Non-significant, With in each column, means followed by the same letter do not differ significantly according to Fisher's least significant difference test (LSD) at 0.05 probability level.

There was no statistically significant difference in interaction effect of cultivars with fungicide seed treatment in Fusarium wilt disease incidence, except in the initial (25 DAE) date of assessment. However, Fusarium wilt disease incidence was significantly $(\mathrm{p}<0.001)$ influenced by sesame cultivars in all assessment dates. At the last assessment date (81 DAE) Fusarium wilt disease incidence in sesame cultivars were ranged $1.97 \%$ to $63.84 \%$ in May-kadra, with mean wilt incidence of 28.25\%; while in Dansha Fusarium wilt disease incidence ranged from $1.9 \%$ to $100 \%$ (mean of $37.39 \%$ wilt incidence). The lowest Fusarium wilt disease incidence was observed from the sesame cultivar Gojam-azene, with values of $1.97 \%$ and $1.9 \%$ in May-kadra and Dansha, respectively. The second lowest Fusarium wilt disease incidence was recorded from Hirhir (8.06\%) in May-kadra and (6.7\%) in Dansha (Table 3). On the other hand, the highest disease incidence was recorded from the sesame varieties Setit-3 (63.84\%) followed by Humera-1 (40.9\%) at May-kadra and from the cultivar Achawuchey (100\%) followed by Setit-3 (62.01\%) at Dansha (Table 3). Among the eight sesame cultivars tested, two (Hirhir and Gojamazene) were in the resistance disease response category; while Setit-2 and Keffif were moderately resistance (moderately susceptible). Sesame cultivars Achawuchey and Setit-3 were the most susceptible to Fusarium wilt disease (Table 3). 
Area under disease progress curve: Interaction effect of fungicide seed treatment with sesame cultivars did not show significant variation with regard to area under disease progress curve (AUDPC). However, there was significant $(p<0.05)$ variation among seed treatments with regard to area under disease progress curve (AUDPC). In May-kadra, the highest AUDPC value (814\%-days) was calculated from the untreated plots; while the lowest AUDPC value (760.6\%-days) was observed from plots treated with Carbendazim 50\% EC (Table 3). Similarly, in Dansha the lowest and the highest AUDPC values (730.2\%-day) and (784.3\%-day) were calculated from seed treatment using Carbendazim 50\% EC and from the untreated control plots, respectively (Table.4).

Area under disease progress curve (AUDPC) value were showed highly significant difference $(\mathrm{p}<0.001)$ among sesame cultivars at both locations. The overall AUDPC value in May-kadra varied from $49.9 \%$-days to $1761.75 \%$-days. The lowest AUDPC value was noted from the cultivar Gojam-azene (49.9\%-days) followed by Hirhir (201.8\%-days); whereas, the highest
AUDPC value was recorded from the variety Setit-3 (1761.75\%-days) followed by Humera-1 (1206.9\%-days) and Setit-1 (1155.7\%-days) in May-kadra (Table 4). In the same way, AUDPC value in sesame cultivars in Dansha varied from $34.5 \%$-days to $2180.2 \%$-days. In Dansha the lowest AUDPC value was calculated from cultivar Gojam-azene (34.5\%-days) followed by Hirhir (121.7\%-days). Whereas, the highest AUDPC value was recorded on the cultivar Achawuchey (2180.2\%-days) followed by the improved variety Setit-3 (1210.7\%-days) (Table 4).

Table 3. Effect of sesame cultivars on Fusarium wilt disease incidence in May-kadra and Dansha, northern Ethiopia during 2018 cropping season

Table 3. Effect of sesame cultivars on Fusarium wilt disease incidence in May-kadra and Dansha, north
Disease incidence (\%)

\begin{tabular}{|c|c|c|c|c|c|c|c|c|c|c|c|c|}
\hline \multirow{3}{*}{$\begin{array}{l}\text { Sesame cultivars (sub- } \\
\text { plot treatments) }\end{array}$} & \multicolumn{6}{|c|}{ May-kadra } & \multicolumn{6}{|c|}{ Dansha } \\
\hline & 25 & 39 & 53 & 67 & 81 & Response & 25 & 39 & 53 & 67 & 81 & Response \\
\hline & DAE & DAE & DAE & DAE & DAE & category & DAE & DAE & DAE & DAE & DAE & category \\
\hline Setit-1 & $2.39 \mathrm{ab}$ & $7.69^{b}$ & $20.10^{\mathrm{b}}$ & $34.26^{c}$ & $39.12^{c}$ & $\mathrm{~S}$ & $2.48^{b}$ & $12.41^{\mathrm{d}}$ & $28.19 c$ & $40.01^{c}$ & $44.91^{c}$ & $\mathrm{~S}$ \\
\hline Setit-2 & $1.0^{\mathrm{cd}}$ & $3.45^{c}$ & $11.36^{c}$ & $18.94^{\mathrm{e}}$ & $22.89 \mathrm{e}$ & MS & $0.47^{c}$ & $3.51^{\mathrm{e}}$ & $9.77^{d}$ & $17.17^{\mathrm{d}}$ & $18.66^{\mathrm{e}}$ & MR \\
\hline Setit-3 & $2.80^{\mathrm{a}}$ & $10.66^{a}$ & $29.27^{a}$ & $52.83^{a}$ & $63.84^{\mathrm{a}}$ & HS & $3.56^{\mathrm{b}}$ & $16.36^{b}$ & $38.36^{\mathrm{b}}$ & $56.23^{\mathrm{b}}$ & $62.01^{b}$ & HS \\
\hline Humera-1 & $2.02^{\mathrm{b}}$ & $7.51^{b}$ & $21.59^{b}$ & $35.86^{b}$ & $40.96^{b}$ & $\mathrm{~S}$ & $3.68^{b}$ & $14.02^{c}$ & $29.45^{c}$ & $39.85^{c}$ & $43.99^{c}$ & $\mathrm{~S}$ \\
\hline Hirhir & $0.50^{\mathrm{d}}$ & $0.78^{d}$ & $3.76^{\mathrm{d}}$ & $5.84^{f}$ & $8.06^{f}$ & $\mathrm{R}$ & $0.00^{c}$ & $0.87^{f}$ & $3.52^{\mathrm{e}}$ & $6.29 \mathrm{e}$ & $6.70^{\mathrm{f}}$ & $\mathrm{R}$ \\
\hline Keffif & $0.78^{\mathrm{cd}}$ & $2.98^{c}$ & $10.38^{c}$ & $18.80^{\mathrm{e}}$ & $23.52^{e}$ & MS & $0.50^{c}$ & $4.47 \mathrm{e}$ & $12.16^{\mathrm{d}}$ & $19.34^{d}$ & $20.94^{d}$ & MS \\
\hline Gojam-azene & $0.50^{d}$ & $0.38^{d}$ & $1.08 \mathrm{e}$ & $1.11^{\mathrm{g}}$ & $1.97 \mathrm{~g}$ & $\mathrm{R}$ & $0.06^{c}$ & $0.34^{\mathrm{f}}$ & $0.97 \mathrm{e}$ & $1.71^{\mathrm{f}}$ & $1.90 \mathrm{~g}$ & $\mathrm{R}$ \\
\hline Achawuchey & $1.13^{c}$ & $3.399^{c}$ & $10.17^{c}$ & $21.62^{d}$ & $25.62^{d}$ & MS & $9.47^{a}$ & $39.15^{a}$ & $76.71^{\mathrm{a}}$ & $95.59^{a}$ & $100^{\mathrm{a}}$ & HS \\
\hline LSD (5\%) & 0.63 & 1.148 & 2.11 & 1.317 & 1.356 & - & 0.882 & 1.484 & 2.72 & 2.502 & 2.219 & - \\
\hline Grand mean & 1.39 & 4.61 & 13.46 & 23.66 & 28.25 & - & 2.529 & 11.39 & 24.89 & 34.52 & 37.39 & - \\
\hline
\end{tabular}

DAE: Date after emergence, HS: Highly susceptible, MR: Moderately resistant, MS: moderately susceptible, R: Resistant, S: Susceptible, Within each column, means followed by the same letter do not differ significantly according to Fisher's least significant difference test (LSD) at 0.05 probability level. 
Table 4. Effect of fungicide seed treatment and sesame cultivars on area under disease progress curve of Fusarium wilt disease in May-kadra and Dansha, northern Ethiopia during 2018 cropping season

\begin{tabular}{lcc}
\hline Treatment & \multicolumn{2}{c}{ AUDPC (\%-days) } \\
\cline { 2 - 3 } Fungicide seed treatment & May-kadra & Dansha \\
\cline { 2 - 3 } Carbendazim 50\% EC & $760.6^{\mathrm{c}}$ & $730.2^{\mathrm{b}}$ \\
Thiram 75\% WP & $789.9^{\mathrm{b}}$ & $757.6^{\mathrm{ab}}$ \\
Control & $814^{\mathrm{a}}$ & $784.3^{\mathrm{a}}$ \\
LSD (5\%) & $17.4^{\mathrm{a}}$ & $37.7^{\mathrm{a}}$ \\
\hline Sesame cultivars & & \\
Setit-1 & $1155.7^{\mathrm{b}}$ & $878.6^{\mathrm{c}}$ \\
Setit-2 & $636.2^{\mathrm{c}}$ & $343.8^{\mathrm{e}}$ \\
Setit-3 & $1761.7^{\mathrm{a}}$ & $1210.7^{\mathrm{b}}$ \\
Humera-1 & $1206.9^{\mathrm{b}}$ & $891.1^{\mathrm{c}}$ \\
Hirhir & $201.8^{\mathrm{d}}$ & $121.7^{\mathrm{f}}$ \\
Keffif & $616.8^{\mathrm{c}}$ & $398.3^{\mathrm{d}}$ \\
Gojam-azene & $49.9^{\mathrm{e}}$ & $34.5^{\mathrm{g}}$ \\
Achawuchey & $676.4^{\mathrm{c}}$ & $2180.2^{\mathrm{a}}$ \\
LSD (5\%) & 60.21 & 50.14 \\
Grand mean & 788.2 & $757.4^{2}$ \\
\hline
\end{tabular}

Within each column, means followed by the same letter do not differ significantly according to Fisher's least significant difference test (LSD) at 0.05 probability level.

Agronomic parameters

Initial and final stand count: There was no statistically significant difference among treatments in the initial stand count. The expected total initial stand count was 30 plats per row and 300 plants per plot. However, there was significant $(\mathrm{p}<0.001)$ difference among treatments in the final stand count taken at maturity. In May-kadra, the highest stand count at maturity was observed from the sesame varieties Gojam-azene (291.5 plants per plot) and Hirhir (276.0 plants per plot); while the lowest stand count was recorded from setit-3 (80.4 plants per plot) followed by Setit-1 (192.7 plants per plot). In Dansha, the highest final stand count was recorded from the cultivar Gojam-azene (288 plants per plot) and Hirhir (277 plants per plot). The lowest final stand count was observed in plots planted with the sesame cultivar Achawuchey ( 0.0 plants per plot) and setit-3 (111 plants per plot) Table (5).

Seed yield: Sesame seed yield was not affected by the interaction effect of varieties and fungicide seed treatment. Although statistically not significant, higher yield was observed in fungicide treated plots compared to the untreated control plots. However, seed yield was significantly $(\mathrm{p}<0.05)$ affected by sesame cultivars. In May-kadra, sesame seed yield was varied from 252.9 $\mathrm{kg} / \mathrm{ha}$ to $622.7 \mathrm{~kg} / \mathrm{ha}$. The highest yield was obtained from the cultivar Hirhir (622.7 kg/ha) followed by Gojam-azene $(606.3 \mathrm{~kg} / \mathrm{ha})$; whereas the lowest seed yield was obtained from the variety Setit-3 $(252.9 \mathrm{~kg} / \mathrm{ha})$ Table (5). In Dansha, the highest yield was obtained from the cultivar Hirhir ( $689.9 \mathrm{~kg} / \mathrm{ha}$ ) followed by Setit$2(534.1 \mathrm{~kg} / \mathrm{ha})$. The lowest yield was obtained from cultivar Achawuchey $(0.0 \mathrm{~kg} / \mathrm{ha})$, which was highly susceptible to Fusarium wilt disease (Table 5).

Association of Fusarium wilt disease with stand count and seed yield: Fusarium wilt disease incidence was significantly correlated with final stand count recorded at maturity $(r=-0.999, \mathrm{p}<0.001)$ in Maykadra and $(r=-0.918, p<0.001)$ in Dansha. Similarly, Fusarium wilt disease incidence was significantly correlated with sesame seed yield $(r=-0.913, p<0.001)$ in May-kadra and $(\mathrm{r}=-0.971, \mathrm{p}<0.001)$ in Dansha. There was negative association between Fusarium wilt disease incidence with stand count recorded at maturity and yield. For one unit increase in disease incidence there was 3.1624 unit stand count and 5.9473 unit yield reduction on sesame cultivars in Maykadra. In the same way in Dansha, for a unit increase in disease incidence there was 2.9574 unit stand count and 6.2113 unit yield reduction (Figure 1). 
Table 5. Stand count and seed yield of sesame cultivars as influenced by Fusarium wilt disease in May-kadra and Dansha, northern Ethiopia during 2018 cropping season

\begin{tabular}{|c|c|c|c|c|c|c|}
\hline \multirow{3}{*}{$\begin{array}{l}\text { Treatments } \\
\text { (Sesame } \\
\text { cultivars) }\end{array}$} & \multicolumn{6}{|c|}{ Agronomic parameters } \\
\hline & \multicolumn{3}{|c|}{ May-kadra } & \multicolumn{3}{|c|}{ Dansha } \\
\hline & $\begin{array}{l}\text { initial stand } \\
\text { count }\end{array}$ & $\begin{array}{c}\text { final stand } \\
\text { count }\end{array}$ & $\begin{array}{c}\text { seed yield } \\
\text { (kg/ha) }\end{array}$ & $\begin{array}{c}\text { initial stand } \\
\text { count }\end{array}$ & $\begin{array}{c}\text { final stand } \\
\text { count }\end{array}$ & $\begin{array}{c}\text { seed yield } \\
\text { (kg/ha) }\end{array}$ \\
\hline Setit-1 & 295 & $192.7^{\mathrm{d}}$ & $440.7^{\mathrm{f}}$ & 293.0 & $161.4^{\mathrm{d}}$ & $421^{\mathrm{e}}$ \\
\hline Setit-2 & 295.9 & $220.5^{b c}$ & $558.1^{\mathrm{c}}$ & 294.1 & $239.2^{c}$ & $534.1^{\mathrm{b}}$ \\
\hline Setit-3 & 298.1 & $80.4^{\mathrm{e}}$ & $252.9 \mathrm{~g}$ & 293.4 & $111^{\mathrm{e}}$ & $217.9^{\mathrm{f}}$ \\
\hline Humera-1 & 293.8 & $202.8^{\mathrm{cd}}$ & $438.1^{\mathrm{f}}$ & 292.8 & $164^{\mathrm{d}}$ & $443.5^{\mathrm{d}}$ \\
\hline Hirhir & 296.9 & $276.7^{a}$ & $622.7^{a}$ & 296.9 & $277^{b}$ & $689.9^{a}$ \\
\hline Keffif & 298 & $226.4^{b}$ & $539.2^{\mathrm{d}}$ & 294.4 & $232.8^{c}$ & $516.7^{c}$ \\
\hline Gojam-azene & 293.4 & $291.5^{\mathrm{a}}$ & $606.3^{\mathrm{b}}$ & 294.4 & $288.8^{\mathrm{a}}$ & $508.7^{c}$ \\
\hline Achawuchey & 294.2 & $222.4 b^{c}$ & $530.4^{\mathrm{e}}$ & 293.1 & $0.00^{\mathrm{f}}$ & $0.00^{\mathrm{g}}$ \\
\hline $\operatorname{LSD}(5 \%)$ & ns & 20.1 & 6.12 & ns & 6.5 & 11.95 \\
\hline Grand mean & 296 & 214 & 498.5 & 294 & 184 & 416.5 \\
\hline
\end{tabular}

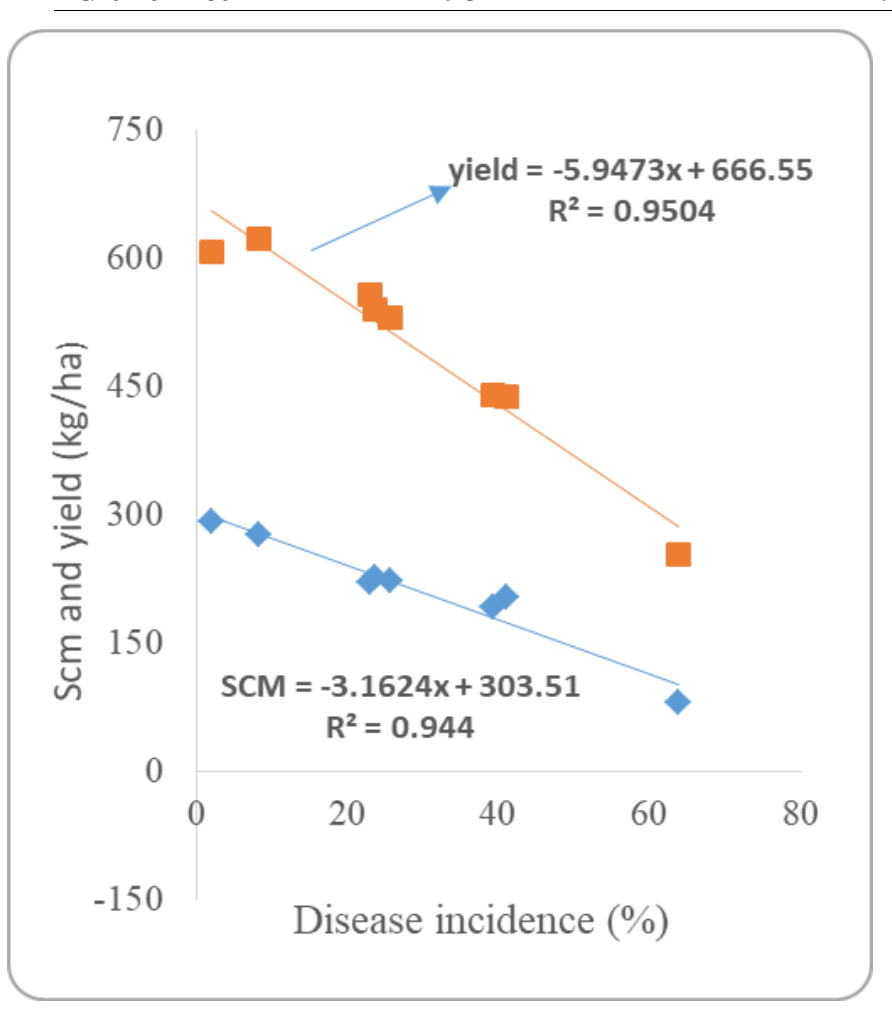

A

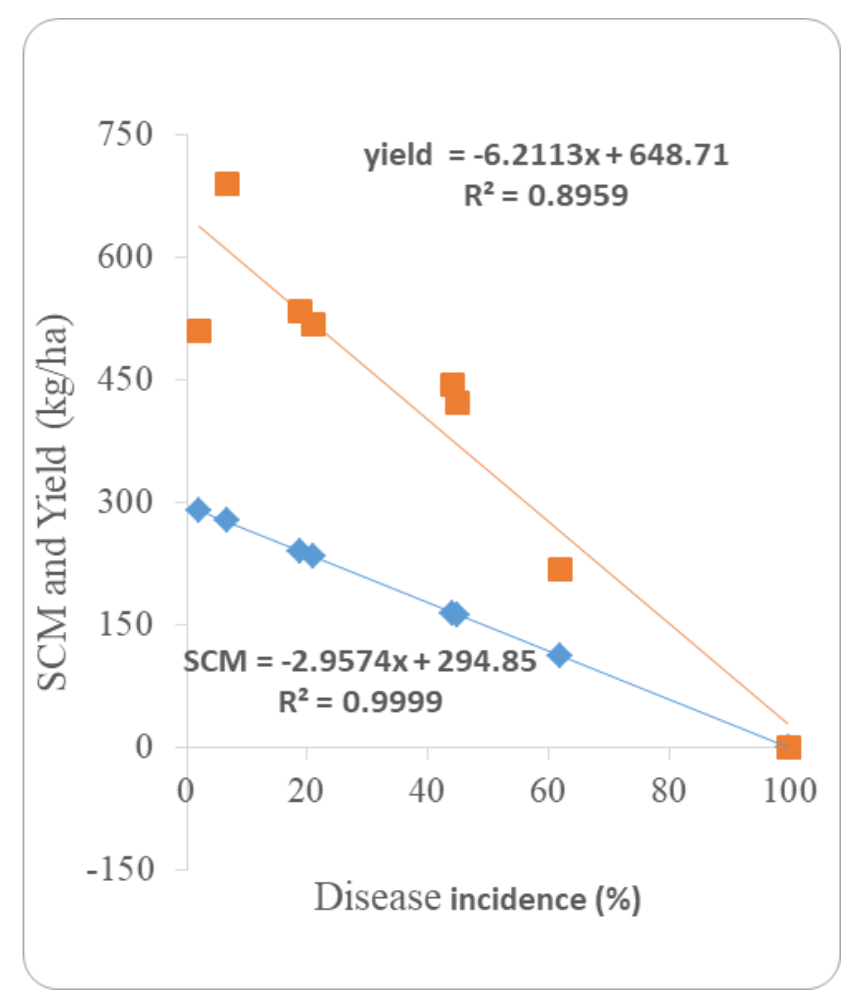

B

SCM: Stand count at maturity

Figure 1. Linear regression between Fusarium wilt disease incidence (\%), stand count at maturity and seed yield

\section{DISCUSSION}

(kg/ha) in May-kadra (a) and Dansha (b), northern Ethiopia during 2018 cropping season

Sesame Fusarium wilt disease caused by Fusarium oxysporum $f$. sp. sesami is one of the major threats for sesame production in western Tigray, northern Ethiopian. In the present study, fungicides with different active ingredients and sesame cultivars were evaluated against Fusarium wilt disease, with the aim to identify fungicide(s) that are effective in controlling the disease as well as selecting best resistance sesame cultivar(s). Fungicide with high effectiveness in controlling the target disease at least in the early crop growth phases was identified in the experiment. Results indicated that seed treatment using Carbendazim 50\% E.C fungicide appeared to be most effective in reducing Fusarium wilt disease incidence compared to Thiram 75\% WP and untreated control plots. This may indicate the 
effectiveness of Carbendazim in suppressing growth and development of the pathogen (i.e inhibition of spore germination and mycelial growth) compared to the other fungicides tested. Carbendazim followed by Thiophanate-methyl among the most effective fungicides in suppressing growth of $F$. oxysporum f. sp. vasinfectum the causative agent of wilt disease in cotton.

Results of the present study indicated that fungicide seed treatments are only effective in preventing stand infection during the early or seedling growth stage of sesame. . This could be due low persistence of the fungicides used as seed treatment. Similar finding was reported by Bayraktar and Dolar (2012) that Fusarium wilt disease is a systemic infection and it is difficult to manage using fungicide seed treatment except protecting plants from fungal attacks during the seedling stage. They further stated that fungicide seed treatment acts temporarily by protecting root infection courts and suppressing disease during the early stages of root development as well as eradicate seed-borne inoculum. In addition, Ajilogba and Babalola (2013) reported that fungicide seed treatment are less effective for controlling soil borne pathogens except the ability to reduce the infection at seedling growth stage of the plant. Bradley (2008) indicated that fungicide seed treatments could prevent stand and yield losses depending on the environmental condition, such as under cool and moist soil conditions.

Sesame cultivars with consistently low Fusarium wilt disease incidence and low AUDPC value were identified. Of all sesame cultivars tested, Gojam-azene and Hirhir were found to have low Fusarium wilt disease incidence and low AUDPC value at both the May-kadra and Dansha field locations. This may indicate that potential resistance genes against $F$. oxysporum $\mathrm{f}$. sp. sesami exists in Ethiopian sesame germplasms. Thus, these cultivars may be useful as source of resistance to $F$. oxysporum $f$. sp. sesami for the development of resistant varieties in the sesame-breeding program, as this pathogen is the most common fungal pathogen associated with sesame in Ethiopia (Terefe and Tulu, 1992). Besides, growing the cultivars that display very low level of disease incidence may reduce damage and yield loss in areas where Fusarium wilt disease is most prevalent.

None of the sesame cultivars evaluated in this study were completely resistant (immune) to Fusarium wilt disease, which is in agreement with previous studies (ElBramawy et al., 2001; Joshi et al., 2012; Radhakrishnan et al., 2014). The present study also indicated that wide range of genetic variation exists among the sesame germplasms with respect to Fusarium wilt infection, with sesame cultivars Achawuchey and Setit-3 tend to exhibit significantly higher Fusarium wilt disease incidence across the two experimental sites. This could be due to the fact that these cultivars may lack the genes for resistance to Fusarium wilt disease and they are susceptible. Thus, they need to be improved though breeding programs. Crop cultivars resistant or tolerant to fungal pathogens produces higher quantities of concentrated exudates to impede pathogen invasion, while the susceptible genotypes either do not produce root exudates toxic to fungal growth or produce compounds that stimulate pathogen growth (Mandal and Sinha, 1991). Results of the present study are in agreement with the findings of Silme and Cagirgan (2010) who had evaluated the resistance levels of 25 sesame genotypes for their resistance to $F$. oxysporum in two soil conditions with a known contamination by virulent pathogen, and reported a great variation in the genotypes. These authors further identified one cultivar recognized as "Birkan" as resistant to the Fusarium wilt disease.

The results of the field studies also indicated that calculating the AUDPC values were able to differentiate the reaction (resistance level) of sesame cultivars to Fusarium wilt disease. Similar to the results of the present study, Madden et al. (2007) were evaluated $F$. oxysporum incidence in common bean performed at different years, location and under different managements, and reported the AUDPC value as effective tool to differentiate the reaction of the genotypes.

The observed low yield in some sesame cultivars such as Setit-3 and Achawuchey in the present study was due to their susceptibility to Fusarium wilt disease. For example stand count in these cultivars was reduced greatly due to Fusarium wilt disease and many of the plants did not produce seed at all, and if they did, the seeds were deformed or shriveled. This was due to the fact that sesame Fusarium wilt disease is most destructive, causes both reduction in plant stand and ultimately the yield. This result is in harmony with the findings of Kavak and Boydak (2006) that reported Fusarium wilt disease infected sesame plants were completely dried and killed in different time periods. Similarly, Gunua (2010) observed that plants infected 
with Fusarium wilt disease normally died within a few days after visible symptoms. Gupta et al. (2018) also observed that Fusarium wilt disease causing a severe plant stand losses right from seedling to maturity of the crop. Overall results pointed out that cultivation of resistant varieties is the best option or effective to mage Fusarium wilt disease. This can also be integrated with other environmentally friendly controlling strategies like good hygiene (avoidance of contamination of seeds, and clearing of debris from previous year's planting.

In conclusion, growing the most resistant cultivars such as Hirhir and Gojam-azene may substantially reduce the level of loss in areas where Fusarium wilt disease is most prevalent. Since the materials included in the present study are limited, further extensive evaluations should continue by including more germplasms. This will increase the chances for selecting sesame material with higher resistance levels. Sesame cultivars with low Fusarium wilt disease incidence may be important as sources of resistance to $F$. oxysporum f. sp. sesami for introduction into advanced breeding programs. The current breeding system should also give attention for resistance to sesame Fusarium wilt in addition to yield and other agronomic parameters for better management of $F$. oxysporum f. sp. sesami.

\section{REFERENCE}

Agrios, G. N. 2005. Plant Pathology 5th ed. Academic Press. Inc., New York, USA. p. 694-697.

Ajilogba, C. F. and 0. O. Babalola. 2013. Integrated Management Strategies for Tomato Fusarium Wilt. Biocontrol Science, 18: 117-127.

Alemaw, G., G. Terefe, B. Weyessa and K. Zewdie. 1997. Lowland Oil crops A three-decade research experience in Ethiopia.

Ashri, A. 1998. Sesame breeding. Plant breeding reviews, 16: 179-228.

Bayraktar, H. and F. S. Dolar. 2012. Pathogenic variability of Fusarium oxysporum f. sp. ciceris isolates from chickpea in Turkey. Pak. J. Bot, 44: 821-823.

Bradley, C. A. 2008. Effect of Fungicide Seed Treatments on Stand Establishment, Seedling Disease, and Yield of Soybean in North Dakota. Plant Disease, 92: 120-125.

CSA (Central Statistical Agency). 2018. Federal Democratic Republic Ethiopia: Central Statistics Agency. Agricultural Sample survey. 2017-2018. Report on Area and Production of crops (private peasant holdings, Meher season), Addis Ababa.
Statistical Bulletin No: 586. I: 10-18.

Dinakaran, D. and S. Mohammed. 2001. Identification of resistant sources to root rot of sesame caused by Macrophomina phaseolina (Tassi.) Goid. Sesame and Safflower Newsletter: 68-71.

Dita, M., M. Barquero, D. Heck, E. S. G. Mizubuti and C. P. Staver. 2018. Fusarium Wilt of Banana: Current Knowledge on Epidemiology and Research Needs toward Sustainable Disease Management. Frontiers in Plant Science, 9.

El-Bramawy, M., K. Veverka, S. Vaverka, M. El-Shazly, M. El-Sattar, M. El-Ashary and S. Ammar. 2001. Evaluation of resistance to Fusarium oxysporum $\mathrm{f}$. sp. seasami in hybrid lines of sesame (Sesamum indicum L.) under greenhouse conditions. PLANT Protection Science-Prague-, 37: 74-79.

El-Bramawy, M., K. Veverka, S. Vaverka, M. El-Shazly, M. El-Sattar, M. El-Ashary and S. Ammar. 2001. Evaluation of resistance to Fusarium oxysporum $\mathrm{f}$. sp. sesami in hybrid lines of sesame (Sesamum indicum L.) under greenhouse conditions. Plant Protection Science, 37: 2-74.

FAO, 2011. Food and Agriculture Organization of the United Nations (FAO) Statistics Division Sesame seed United Nations, New York, United States.

Gunua, T.-G. 2010. A review of sweet potato scab and studies on Fusarium wilt of sweet potato (Ipomoea batatas (L.) Lam.) and approaches to its management.

Gupta, K., K. Naik and R. Bisen. 2018. Status of sesame diseases and their integrated management using indigenous practices. International Journal of Chemical Studies, 6: 1945-1952.

Joshi, M. 2012. Screening of Resistant Varieties and Antagonistic Fusarium oxysporum for Biocontrol of Fusarium Wilt of Chilli. Journal of Plant Pathology \& Microbiology, 03.

Kassa, A., T. Tesfaye, A. Azanaw, A. Adebabay and M. Azanaw. Performance of sesame (Sesamum indicum L.) varieties in the Metema areas. Amhara Agricultural Research Institute, 1: 229.

Kavak, H. and E. Boydak. 2006. Screening of the Resistance Levels of 26 Sesame Breeding Lines to Fusarium Wilt Disease. Plant Pathology Journal, 5: 157-160.

Leslie, J. F. and B. A. Summerell. 2008. The Fusarium laboratory manual. John Wiley \& Sons.

Madden, L. V., G. Hughes and F. Van Den Bosch. 2007. 
The study of plant disease epidemics.

Mandal, N. and A. Sinha. 1991. Differential effects of root exudates and extracts from tomato cultivars on Fusarium oxysporum f. sp. lycopersici in relation to their disease reaction. Journal of Mycopathological Research, 29: 9-16.

Mondal, N., K. V. Bhat and P. S. Srivastava. 2010. Variation in Fatty Acid Composition in Indian Germplasm of Sesame. Journal of the American Oil Chemists' Society, 87: 1263-1269.

Radhakrishnan R., S. Kang, P. Park, S. Lee, I. Baek and I. Lee. 2014. An Evaluation of Resistance to Fusarium Disease in Korean Sesame (Sesamum indicum L.) Germplasm. $3^{\text {rd }}$ International Conference on Applied Life Sciences. 18-20 September, 2014, Malaysia, Republic of Korea.

SBN.2013. Sesame Business Network (SBN) Support Programme in Northwest Ethiopia Launching, Workshop proceeding May 15-16, 2013 Gondar, Ethiopia.

Silme, R. S. and M. I. Cagirgan. 2010. Screening for resistance to Fusarium wilt in induced mutants and world collection of sesame under intensive management. Turkish journal of field crops, 15: 89-93.

Singh, A. K., R. Tomar, B. Kasana, Y. Rikhari and P. Kushwaha. 2016. Integrated wilt management in chickpea (Cicer aritinum L.) in Bundelkhand region. Indian Research Journal of Extension Education, 16: 65-69.

Smith, I. M., J. Dunez, D. Phillips, R. Lelliott and S. Archer. 2009. European handbook of plant diseases. John Wiley \& Sons.

Stover, R. H. 1962. Studies on fusarium wilt of bananas: viii. differentiation of clones by cultural interaction and volatile substances. Canadian Journal of Botany, 40: 1467-1471.

Terfe, G. and A. Tulu. 1992. Groundnut and sesame diseases in Ethiopia. First National Oilseeds Workshop, Addis Abeba (Ethiopia), 3-5 Dec 1991. IAR.

Webster, J. M. 1970. George N. AGRIOS: Plant Pathology. Academic Press, New York, 1969: 629 p. \$ 14.00. Nematologica, 16: 158.

\section{Contribution of Authors:}

Assefa A. Kebede

Hadush Tsehaye
: Conceive idea, conduct research, and write manuscript.

: Help in conducting research, data analysis and review manuscript. 